\title{
PENGEMBANGAN E-MODUL FISIKA BERBASIS MULTIPLE REPRSENTATION UNTUK MELATIHKAN KETERAMPILAN PEMECAHAN MASALAH SISWA
}

\author{
Mazetha Ramadayanty*1, Sutarno $^{2}$, Eko Risdianto ${ }^{3}$ \\ ${ }^{1,3}$ Program Studi Pendidikan Fisika FKIP, Universitas Bengkulu, Bengkulu \\ ${ }^{2}$ Program Studi Pendidikan Fisika FKIP, Universitas Bengkulu, Bengkulu \\ Jl. WR Supratman, Kandang Limun, Bengkulu 38123 \\ e-mail ${ }^{* 1}:$ mazetharamadayanty@gmail.com
}

\begin{tabular}{|l|l|l|r} 
Diterima 3 Februari 2021 & Direvisi 7 April 2021 & Disetujui 19 April 2021 & Dipublikasikan 29 April 2021
\end{tabular}

https://doi.org/10.33369/jkf.4.1.17-24

\begin{abstract}
ABSTRAK
Penelitian ini merupakan penelitian dan pengembangan (R\&D) yang bertujuan untuk mendeskripsikan kelayakan dan karakteristik e-modul fisika berbasis multiple representation untuk melatihkan keterampilan pemecahan masalah siswa SMA pada materi alat optik. Model pengembangan yang digunakan pada penelitian ini adalah model pengembangan 3D yaitu define, design, dan develop. Tahap define terdiri dari merancang instrumen untuk tahap define, analisis RPP, analisis perangkat pembelajaran (modul). Tahap design terdiri dari rancangan e-modul dan rancangan instrumen untuk mengevaluasi $e$-modul. Tahap develop terdiri dari pengembangan instrumen untuk mengevaluasi $e$-modul dan validasi ahli serta revisi berdasarkan hasil validasi ahli. Berdasarkan hasil validasi ahli, diperoleh persentase skor rata-rata pada aspek media adalah $78 \%$ dengan kategori valid, aspek isi sebesar $76 \%$ dengan kategori valid, aspek penyajian sebesar $81 \%$ dengan kategori sangat valid dan aspek bahasa sebesar $76 \%$ dengan kategori valid dengan nilai rata-rata keseluruhan sebesar 78\% dengan kategori valid. Berdasarkan hasil validasi yang telah dilakukan oleh ahli dapat disimpulkan bahwa e-modul yang dikembangkan sudah "layak" untuk digunakan. Karakteristik $e$-modul antara lain: isi e-modul berbasis multiple representation, representasi yang digunakan ditunjukkan untuk menstimulus keterampilan pemecahan masalah siswa dan kegiatan pendahuluan pembelajaran serta soal pada e-modul melatihkan keterampilan pemecahan masalah siswa.
\end{abstract}

Kata kunci: Penelitian dan Pengembangan, e-modul, multiple representation, keterampilan pemecahan masalah

\begin{abstract}
This research was a research and development (R\&D) which aims to describe the feasibility and characteristics of multiple representation-based physics e-modules to train high school students' problem solving skills in optical instrument material. The development model used in this study was a 3D development model, namely define, design, and develop. The define stage consists of designing instruments for the define stage, RPP analysis, analysis of learning tools (modules). The design stage consists of e-module design and instrument design for evaluating the e-module. The develop stage consists of developing instruments for evaluating the e-module and expert validation and revisions based on the results of expert validation. Based on the results of expert validation, the percentage of the average score on the media aspect is $78 \%$ with the valid category, the content aspect is $76 \%$ with the valid category, the presentation aspect is $81 \%$ with the very valid category and the language aspect is $76 \%$ with the valid category with the value the overall average is $78 \%$ with the valid category. Based on the validation results that have been carried out by experts, it can be concluded that the e-module developed is feasible with the characteristics of e-module, including: the content of emodule based on multiple representation, the representation used is shown to stimulate student problem solving skills and preliminary learning activities as well as questions on the e-module train students' problem solving skills.
\end{abstract}

Keywords: Research and Development, e-module, multiple representation, problem solving skills

\section{PENDAHULUAN}

Perkembangan ilmu pengetahuan dan teknologi yang semakin pesat di abad ke-21 menuntut peningkatan kualitas sumber daya manusia dan kualitas pendidikan yang lebih baik. Kompetensi 
inti yang harus dicapai dalam kurikulum 2013 adalah kompetensi pengetahuan dan keterampilan. Perkembangan zaman yang telah bergeser ke era digital, dunia pendidikan juga telah beradaptasi dengan menggunakan teknologi digital. Penggunaan teknologi digital terbukti membantu siswa memahami materi pelajaran dan mampu menjawab berbagai permasalahan di dalam proses pembelajaran yang tidak dapat dilakukan oleh media konvensional. Penggunaan teknologi digital tersebut adalah berupa bahan ajar multimedia yang disajikan secara digital menggunakan komputer/laptop ataupun smartphone. Salah satu bahan ajar itu adalah $e$-modul.

Fisika merupakan salah satu cabang IPA yang mempelajari benda-benda di alam secara fisik dan dituliskan secara matematis agar dapat dimengerti oleh manusia dan dimanfaatkan untuk kesejahteraan umat manusia (1). Pengemasan bahan ajar fisika selama ini masih bersifat linier, yaitu bahan ajar yang hanya menyajikan konsep dan prinsip, contoh-contoh soal dan pemecahannya, dan soal-soal latihan. Bahan ajar kurang dikaitkan dengan masalah-masalah real yang ada di seputar siswa sehingga kurang memberi peluang kepada siswa untuk mengembangkan keterampilan dalam merumuskan masalah, memecahkan masalah, dan mengembangkan pemahaman. Fisika tidak lepas dari penguasaan konsep, menerapkannya dalam penyelesaian masalah fisika dan bekerja secara ilmiah (2).

Ketika siswa mempelajari fisika, siswa dituntut untuk menguasai representasi-representasi berbeda seperti simulasi, grafik, konseptual/keterangan lisan, rumus, serta gambar atau diagram secara bersamaan. Representasi adalah suatu konfigurasi (bentuk atau susunan) yang dapat menggambarkan, mewakili atau melambangkan sesuatu dalam suatu cara. Representasi juga merupakan sesuatu yang mewakili, menggambarkan atau meyimbolkan obyek atau proses. Multi representasi berarti mempresentasi ulang konsep yang sama dengan format yang berbeda, termasuk verbal, gambar, grafik dan matematik. Multi representasi memliki tiga fungsi utama yaitu sebagai pelengkap, pembatas interprestasi, dan pembangun pemahaman.

Pembelajaran fisika dalam kelas saat ini cenderung menekankan pada penguasaan konsep dan mengesampingkan kemampuan pemecahan masalah fisika siswa sehingga kemampuan siswa dalam memecahkan permasalahan masih tergolong rendah. Kemampuan pemecahan masalah sangat dibutuhkan siswa dalam pembelajaran fisika. Hal ini dikarenakan aktivitas pemecahan masalah dapat membantu siswa untuk mengkonstruksi pengetahuan baru dan memfasilitasi pembelajaran fisika. Salah satu bentuk keterampilan berpikir tingkat tinggi yang harus dibekalkan adalah keterampilan pemecahan masalah. Keterampilan ini sangat penting bagi siswa mengingat mereka saat ini hidup dalam dunia yang semakin kompleks (3) .

Menurut Polya (1973) ada empat tahap pemecahan masalah yaitu memahami masalah, merencanakan penyelesaian masalah, melakukan perencanaan masalah, dan melihat kembali hasil yang diperoleh (4). Apabila penyelesaian yang diharapkan tidak berjalan sebagaimana yang diinginkan berarti telah terjadi didalam tahap-tahap awal sehingga setiap pelaku pemecah masalah harus memulai kembali berfikir dari awal yang bermasalah untuk mendapatkan pemahaman menyeluruh mengenai masalah yang sedang dihadapi (5). Sebagai upaya meningkatkan kemampuan pemecahan masalah peserta didik diperlukan suatu bahan ajar yang dapat menunjang proses pembelajaran seperti modul, LKPD, buku paket, buku elektronik dan lain-lain.

Bahan ajar yang memudahkan tercapainya tujuan pembelajaran efektif, efisien dan dimiliki guru dan siswa adalah modul (6). Bahan ajar yang ada sekarang belum memanfaatkan teknologi yang sudah ada, seperti $e$-modul. E-modul adalah alat atau sarana pembelajaran yang berisi materi, metode, batasan-batasan dan cara mengevaluasi yang dirancang secara sistematis dan menarik untuk mencapai kompetensi yang diharapkan sesuai dengan tingkat kompleksitasnya secara elektronik. Kelebihannya dibandingkan dengan modul cetak adalah sifatnya yang interaktif memudahkan dalam navigasi, memungkinkan menampilkan/memuat gambar, audio, video dan animasi serta dilengkapi tes/kuis formatif yang memungkinkan umpan balik otomatis dengan segera (7) .

Peserta didik yang memiliki minat besar terhadap pembelajaran akan cenderung tertarik dalam pembelajaran sehingga memudahkan peserta didik menerima materi yang disampaikan oleh guru (8). Kemampuan berpikir tingkat tinggi ini bukan hanya perihal mengerjakan soal dengan

Pengembangan E-Modul Fisika Berbasis Multiple Reprsentation untuk Melatihkan Keterampilan Pemecahan Masalah...

Mazetha Ramadayanty, Sutarno, Eko Risdianto 
menggunakan rumus yang sudah di hafal, tetapi berpikir tingkat tinggi merupakan kemampuan menganalisis bisa dilihat dari memecahkan masalah menjadi beberapa bagian, kemudian mencari hubungannya (9).

Penelitian sebelumnya mengenai e-modul fisika berbasis multiple representation dengan judul Pengembangan Modul Pembelajaran Berbasis Multirepresentasi Pada Pembelajaran Fisika di Sma/Ma menghasilkan modul yang memperoleh hasil validasi kajian instruktusional meliputi aspek kelayakan isi, kebahasaan, penyajian dan kegrafikaan dengan rata-rata 3,78 dengan kategori cukup valid. Validasi kajian teknis meliputi aspek format dan bahasa diperoleh rata-rata 4 dengan kategori valid (10). Karena belum ada penggunaan dalam materi alat optik maka peneliti melakukan penelitian ini.

Berdasarkan uraian diatas maka dilakukan penelitian yang berjudul "Pengembangan E-Modul Fisika Berbasis Multiple Representation untuk Melatihkan Pemecahan Masalah Siswa". Adapun tujuan penelitian ini adalah mengetahui kelayakan dan karakteristik e-modul yang dikembangkan pada materi alat optik.

\section{METODE PENELITIAN}

Jenis penelitian ini merupakan penelitian pengembangan dengan desain model 4-D oleh Thiagarajan dan Semmel yang meliputi define, design, develop dan disseminate yang direduksi menjadi 3-D desain model 3-D meliputi define, design dan develop Setyandaru, Wahyuni \& Putra (2017). Tahap pada penelitian ini hanya meliputi define, design, dan develop. Tahapan penelitian pada model ini bisa dilihat pada gambar 1.

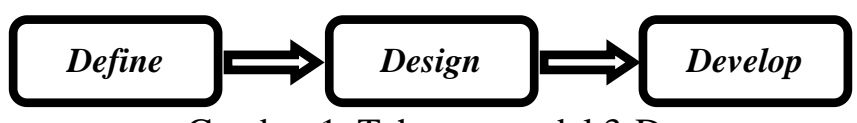

Gambar 1. Tahapan model 3-D

Produk yang dikembangkan adalah e-modul fisika berbasis multiple representation untuk melatihkan keterampilan pemecahan masalah siswa pada materi alat optik. Uji validitas dilakukan menggunakan lembar expert judgment dengan 4 aspek yaitu aspek media, isi, penyajian dan bahasa. Kriteria penilaian terhadap instrumen penelitian dapat dilihat pada tabel 1 .

Tabel 1. Kriteria Penilaian ahli terhadap instrumen penelitian

\begin{tabular}{cc}
\hline Kriteria & Skor \\
\hline Sangat Sesuai (SS) & 4 \\
Sesuai (S) & 3 \\
Tidak Sesuai (TS) & 2 \\
Sangat Tidak Sesusai (STS) & 1 \\
\hline
\end{tabular}

Data hasil validasi selanjutnya dianalisis menggunakan persamaan:

$$
\text { \%Interpretasi skor }=\frac{\sum \text { Skor perolehan }}{\sum \text { Skor maksimum }} X 100 \%
$$

Setelah didapatkan interpretasi skor dengan menggunakan rumus tersebut, maka diperoleh persentase skor. Persentase skor dapat dilihat pada tabel 2.

\begin{tabular}{cc}
\multicolumn{2}{c}{ Tabel 2. Interpretasi Skor Penilaian } \\
\hline Persentase & Kategori \\
\hline $0 \%-20 \%$ & Sangat tidak valid \\
$21 \%-40 \%$ & Tidak valid \\
$41 \%-60 \%$ & Cukup valid \\
$61 \%-80 \%$ & Valid \\
$81 \%-100 \%$ & Sangat valid \\
\hline
\end{tabular}


Modul yang dikembangkan dapat dikatakan layak apabila memenuhi kriteria sangat valid, valid dan cukup valid dengan persentase $\geq 51 \%$ (14).

\section{HASIL DAN PEMBAHASAN}

\subsection{Hasil}

\subsubsection{Define (Tahap Pendefinsian)}

Pada bab sebelumnya telah dipaparkan pada tahap define dilakukan kegiatan untuk mendefinisikan syarat-syarat dan menetapkan kebutuhan pengembangan yang akan dilakukan (14). Tahap ini mencangkup hasil penyusunan instrumen untuk tahap define, hasil analisis rencana pelaksanaan pembelajaran (RPP), hasil analisis perangkat pembelajaran yang berupa modul dan hasil analisis kebutuhan pengembangan.

\subsubsection{Design (Tahap Perancangan)}

Hasil rancangan produk yang akan dikembangkan yaitu berupa rancangan awal e-modul berbasis multiple representation untuk melatihkan pmecahan masalah siswa. E-modul disusun berdasarkan rancangan yang telah dijabarkan pada bab sebelumnya yang terdiri dari: cover, identitas penulis, kata pengantar, kompetensi inti dan kompetensi dasar, petunjuk penggunaan, komponen isi (peta konsep dan kegiatan pembelajaran), glosarium, daftar pustaka dan kunci jawaban.

\subsubsection{Develop (Tahap Pengembangan)}

Setelah tahap perancangan produk, selanjutnya dolakukan tahap pengembangan $e$-modul kemudian validasi dan revisi berdasarkan hasil validasi. Perhitungan uji ahli untuk aspek media dapat dilihat pada tabel 3 .

\begin{tabular}{ccccc}
\multicolumn{5}{c}{ Tabel 3. Hasil uji validasi aspek media oleh ahli dan praktisi } \\
\hline Validator & $\begin{array}{c}\sum \text { Skor } \\
\text { perolehan }\end{array}$ & $\begin{array}{c}\sum \text { Skor } \\
\text { maksimum }\end{array}$ & \%interpretasi skor $=\frac{\sum \text { Skor perolehan }}{\sum \text { Skor maksimum }} \times \mathbf{1 0 0 \%}$ & Kategori \\
\hline Ahli 1 & 19 & 24 & $80 \%$ & Valid \\
Ahli 2 & 19 & 24 & $80 \%$ & Valid \\
Praktisi & 18 & 24 & $75 \%$ & Valid \\
Total & $\mathbf{5 6}$ & $\mathbf{7 2}$ & $\mathbf{7 8 \%}$ & Valid \\
\hline
\end{tabular}

Berdasarkan tabel 3, terlihat bahwa aspek media dalam e-modul yang dikembangkan dengan rata-rata persentase $78 \%$ dalam kategori valid. Selanjutnya untuk perhitungan uji ahli pada aspek isi dapat dilihat pada tabel 4.

Tabel 4. Hasil uji validasi aspek isi oleh ahli dan praktisi

\begin{tabular}{ccccc}
\hline Validator & $\begin{array}{c}\sum \text { Skor } \\
\text { perolehan }\end{array}$ & $\begin{array}{c}\sum \text { Skor } \\
\text { maksimum }\end{array}$ & \%interpretasi skor $=\frac{\sum \text { Skor perolehan }}{\sum \text { Skor maksimum }} \times \mathbf{1 0 0} \%$ & Kategori \\
\hline Ahli 1 & 44 & 60 & $73 \%$ & Valid \\
Ahli 2 & 46 & 60 & $77 \%$ & Valid \\
Praktisi & 45 & 60 & $75 \%$ & Valid \\
Total & $\mathbf{1 3 6}$ & $\mathbf{1 8 0}$ & $\mathbf{7 6 \%}$ & Valid \\
\hline
\end{tabular}

Tabel 4 memperlihatkan bahwa aspek isi dalam $e$-modul yang dikembangkan dengan rata-rata persentase $76 \%$ dalam kategori valid. Selanjutnya untuk perhitungan uji ahli untuk aspek penyajian dapat dilihat pada tabel 5.

Tabel 5. Hasil uji validasi aspek penyajian oleh ahli dan praktisi

\begin{tabular}{ccccc}
\hline Validator & $\begin{array}{c}\sum \text { Skor } \\
\text { perolehan }\end{array}$ & $\begin{array}{c}\sum \text { Skor } \\
\text { maksimum }\end{array}$ & \%interpretasi skor $=\frac{\sum \text { Skor perolehan }}{\sum \text { Skor maksimum }} \times \mathbf{1 0 0} \%$ & Kategori \\
\hline Ahli 1 & 10 & 12 & $83 \%$ & Sangat valid \\
Ahli 2 & 10 & 12 & $83 \%$ & Sangat valid \\
Praktisi & 9 & 12 & $75 \%$ & Valid \\
Total & $\mathbf{2 9}$ & $\mathbf{3 6}$ & $\mathbf{8 1 \%}$ & Sangat valid \\
\hline
\end{tabular}

Dari tabel 5, terlihat bahwa aspek penyajian dalam $e$-modul yang dikembangkan dengan ratarata persentase $81 \%$ dalam kategori valid. Selanjunya untuk perhitungan uji ahli untuk aspek bahasa dapat dilihat pada tabel 6 . 


\begin{tabular}{lllcl}
\hline \multicolumn{5}{c}{ Tabel 6. Hasil uji validasi aspek bahasa oleh ahli dan praktisi } \\
\hline Validator & $\begin{array}{l}\sum \text { Skor } \\
\text { perolehan }\end{array}$ & $\begin{array}{l}\sum \text { Skor } \\
\text { maksimum }\end{array}$ & \%interpretasi skor $=\frac{\sum \text { Skor perolehan }}{\sum \text { Skor maksimum }} \times \mathbf{1 0 0} \%$ & Kategori \\
& 27 & 36 & $75 \%$ & Valid \\
Ahli 1 & 28 & 36 & $78 \%$ & Valid \\
Ahli 2 & 28 & 36 & $75 \%$ & Valid \\
Praktisi & 27 & $\mathbf{1 0 8}$ & $\mathbf{7 6 \%}$ & Valid \\
Total & $\mathbf{8 2}$ & &
\end{tabular}

Berdasarkan tabel 6 , terlihat bahwa aspek bahasa dalam $e$-modul yang dikembangkan dengan rata-rata persentase $76 \%$ dalam kategori valid. Hasil akhir uji validasi oleh ahli dapat dilihat pada tabel 7 .

Tabel 7. Hasil akhir uji validasi

\begin{tabular}{ccc}
\hline ASPEK & NILAI RATA-RATA & KATEGORI \\
\hline Media & $78 \%$ & Valid \\
Isi & $76 \%$ & Valid \\
Penyajian & $81 \%$ & Sangat valid \\
Bahasa & $76 \%$ & Valid \\
Rata-rata & $\mathbf{7 8 \%}$ & Valid
\end{tabular}

Tabel 7 menunjukkan bahwa hasil uji yang dilakukan oleh ahli dan praktisi $e$-modul fisika berbasis multiple representation untuk melatihkan keterampilan pemecahan masalah siswa pada materi alat optik dengan rata-rata persentase sebesar $78 \%$ dalam kategori valid dan dinyatakan layak dengan adanya beberapa revisi.

Produk akhir setelah dilakukan revisi berdasarkan hasil validasi ahli yaitu berupa e-modul fisika berbasis multiple representation untuk melatihkan keterampilan pemecahan masalah siswa pada materi alat optik. E-modul ini terbagi menjadi tiga bagian yang terdiri dari bagian awal, bagian ini dan bagian akhir.

Bagian awal berisi cover, kata pengantar, identitas penulis dan petunjuk penggunaan. Cover didesain semenarik mungkin dengan gambar yang berhubungan dengan materi alat optik. Cover emodul dapat dilihat pada gambar dibawah ini.

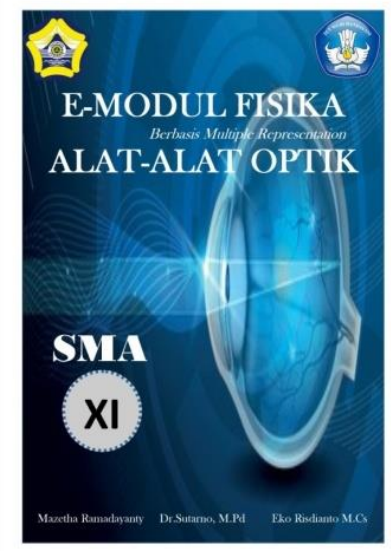

Gambar 2. Cover e-modul

Bagian inti terdiri dari kompetensi inti, kompetensi dasar dan indikator, peta konsep, tujuan pembelajaran, kegiatan pendahuluan, uraian materi dan soal evaluasi. E-modul ini berisi 5 subbab materi alat optik yaitu mata, kamera, lup, mikroskop dan teropong. Setiap subbab materi dijelaskan dengan multiple representation yang berisi uraian materi, gambar alat-alat optik dan bagian-bagian dari alat optik, grafik pembentukan bayangan yang terjadi pada alat optik dan matematis dengan besaran-besaran fisis apa saja yang digunakan pada materi alat optik. Pada $e$-modul terdapat video yang mendukung mengenai pembentukan bayangan yang terjadi pada mata, kamera, lup, mikoskop dan teropong. Dibawah ini merupakan salah satu contoh video yang ada didalam $e$-modul. 


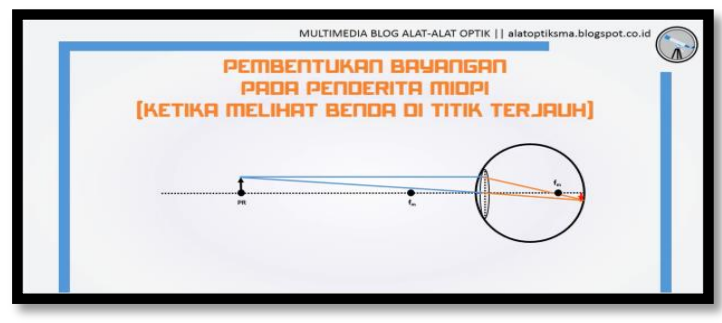

Gambar 3. salah satu tampilan video yang terdapat pada e-modul

Berbeda dengan modul yang digunakan disekolah yang belum berbasis multiple representation dan masih menggunakan modul cetak sehingga tidak bisa melampirkan video yang mendukung dalam penyampaian materi.

Pada $e$-modul bagian melatihkan keterampilan pemecahan masalah terdapat pada awal kegiatan pembelajaran, contoh soal dan soal evalusi. Soal yang terdapat pada e-modul untuk melatihkan pemecahan masalah siswa dengan diberikan langkah-langkah penyelesaian soal berdasarkan langakah-langkah dari pemecahan masalah. Dengan begitu keterampilan siswa bisa terlatih setelah menggunakan e-modul ini. Dibawah ini merupakan salah satu contoh langkah-langkah pemecahan masalah yang terdapat pada penyelesaian soal yang ada didalam $e$-modul.

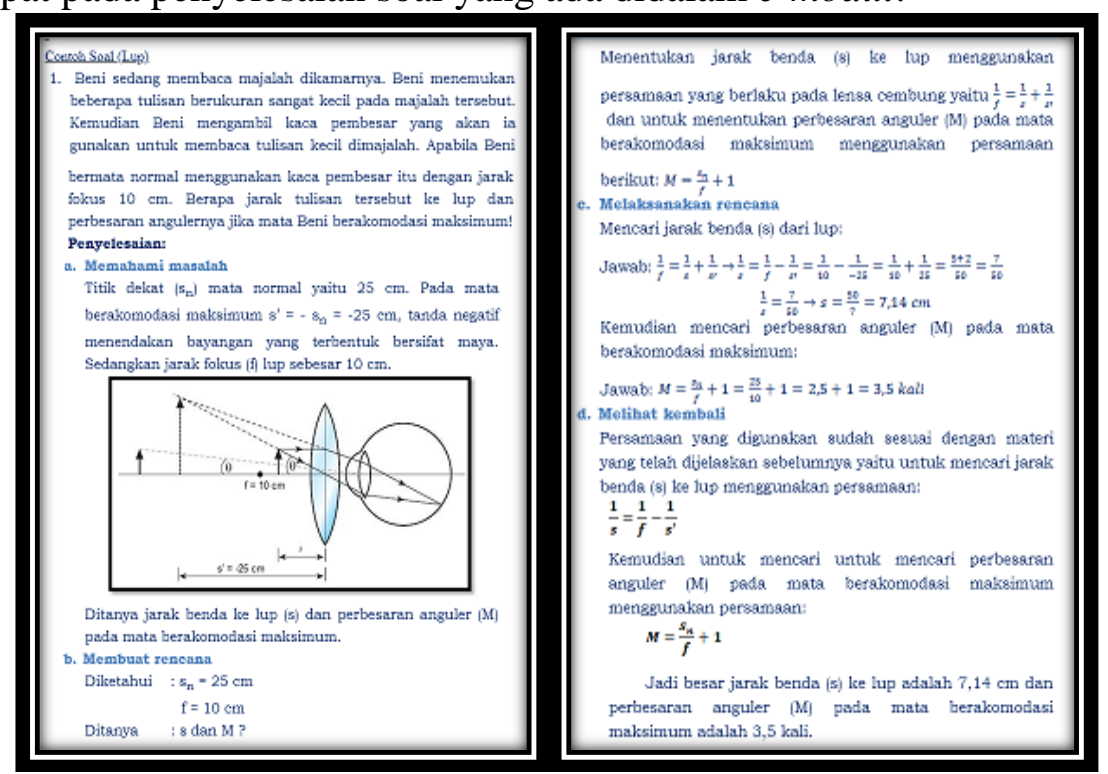

Gambar 4. salah satu langkah-langkah pemecahan masalah pada soal

Sedangkan pada modul yang disekolah belum menggunakan langkah-langkah pemecahan masalah pada penyelesaian soal. Sehingga keterampilan pemecahan siswa belum terlatih.

Bagian akhir modul terdiri dari rangkuman, glosarium, daftar pustaka dan kunci jawaban soal evaluasi. Kunci jawaban dibuat untuk mengetahui sejauh mana siswa memahami materi yang terdapat dalam modul dengan langkah-langkah pemecahan masalah.

\subsection{Pembahasan}

Tahap define (pendefinisian) didapatkan hasil analisis RPP yang digunakan disekolah sudah sesuai dengan komponen RPP kurikulum 2013 menurut Permendikbud Nomor 22 tahun 2016. Analisis modul yang ada di SMAN 7 Kota Bengkulu didapatkan hasil bahwa modul disekolah tersebut belum menggunakan modul elektronik (e-modul) dan modul yang ada belum berbasis multiple representation dan belum dilengkapi dengan langkah-langkah pemecahan masalah dalam menyelesaikan soal. Tahap design (perancangan), rancangan tersebut terdiri dari: cover e-modul, identitas penulis, kata pengantar, kompetensi inti dan kompetensi dasar, petunjuk penggunaan, komponen isi yang yaitu peta konsep dan kegiatan pembelajaran yang berisi 1) tujuan pembelajaran, 2) uraian materi berisikan banyak representasi (multiple representation) terutama representasi gambar, selain itu juga terdiri dari representasi verbal, representasi grafik dan representasi matematis, 3) rangkuman, 4) lembar kegiatan peserta didik, 5) latihan soal dan soal evaluasi yang melatihkan keterampilan pemecahan masalah siswa, glosarium, daftar pustaka dan 
kunci jawaban. Rancangan instrumen untuk mengevaluasi $e$-modul dibuat sesuai dengan kisi-kisi yang terdapat pada bab sebelumnya. Setelah tahap design (perancangan) yang telah dinilai oleh dosen pembimbing dan kemudian direvisi, tahap selanjutnya adalah develop (pengembangan) yaitu melakukan validasi terhadap e-modul dan revisi berdasarkan hasil validasi. Hasil akhir dari penelitian ini adalah $e$-modul fisika berbasis multiple representation untuk melatihkan keterampilan pemecahan masalah siswa pada materi alat optik.

Berdasarkan hasil keseluruhan dari uji validasi aspek media, aspek isi, aspek penyajian dan aspek bahasa yang dilakukan oleh 2 orang ahli dan 1 orang praktisi maka dikatakan bahwa $e$-modul berbasis multiple representation untuk melatihkan keterampilan pemecahan masalah siswa yang dikembangkan termasuk dalam kategori valid dengan presentase rata-rata sebesar $78 \%$ dari $100 \%$. E-Modul yang dikembangkan dapat dikatakan layak apabila memenuhi kriteria sangat valid, valid dan cukup valid dengan persentase $\geq 51 \%$. Hal ini berarti $e$-modul fisika yang dikembangkan sudah memenuhi aspek media, isi, penyajian dan bahasa sehingga dapat disimpulkan bahwa e-modul berbasis multiple representation untuk melatihkan keterampilan pemecahan masalah siswa sudah layak akan tetapi perlu adanya beberapa revisi. Hasil penelitian ini relevan dengan penelitian yang berjudul Pengembangan Modul Pembelajaran Kontekstual Berbasis Multiple Representations Pada Materi Fluida Statis yang menghasilkan produk yang layak untuk digunakan sebagai bahan ajar, dikarenakan telah teruji kemenarikan, kemudahan, kemanfaatan, serta keefektifannya.

Karakteristik e-modul yang telah dikembangkan yaitu berdasakan penelitian sebelumnya dengan judul "pengembangan modul elektronik fisika berbasis multirepresentasi pada materi fluida statis di sekolah menengah atas" e-modul disajikan dengan banyak representasi yaitu representasi verbal, representasi gambar, representasi grafik dan representasi matematis (15). Menyajikan modul elektronik yang bisa dibuka dimana saja dan kapan saja. Setiap subbab materi dijelaskan dengan multiple representation yang berisi uraian materi, gambar alat-alat optik dan bagian-bagian dari alat optik, grafik pembentukan bayangan yang terjadi pada alat optik dan matematis dengan besaranbesaran fisis apa saja yang digunakan pada matri alat optik. Pada e-modul terdapat video yang mendukung mengenai pembentukan bayangan yang terjadi pada mata, kamera, lup, mikoskop dan teropong. Pada $e$-modul bagian melatihkan keterampilan pemecahan masalah terdapat pada awal kegiatan pembelajaran, contoh soal dan soal evalusi. Soal yang terdapat pada e-modul untuk melatihkan pemecahan masalah siswa dengan diberikan langkah-langkah penyelesaian soal berdasarkan langakah-langkah dari pemecahan masalah. Dengan begitu keterampilan siswa bisa terlatih setelah menggunakan $e$-modul ini.

\section{SIMPULAN DAN SARAN}

\subsection{Simpulan}

Berdasarkan pengembangan yang telah dilakukan dapat disimpulkan bahwa (1) berdasarkan validasi yang telah dilakukan oleh ahli dan praktisi pada $e$-modul yang telah dikembangkan dalam kategori "valid" sehingga dapat disimpulkan bahwa $e$-modul fisika berbasis multiple representation untuk melatihkan keterampilan pemecahan masalah siswa layak digunakan. (2) Karakteristik $e$ modul berbasis multiple representation yang telah berhasi; dikembangkan adalah (a) Penjelasan materi dalam setiap subbab materi didukung oleh representasi berupa uraian, gambar, grafik dan matematis serta video. Setiap subbab materi dijelaskan dengan multiple representation yang berisi uraian materi, gambar alat-alat optik dan bagian-bagian dari alat optik, grafik pembentukan bayangan yang terjadi pada alat optik dan matematis dengan besaran-besaran fisis apa saja yang digunakan pada matri alat optik, (b) Representasi yang digunakan ditunjukkan untuk menstimulus keterampilan pemecahan masalah siswa, (c) Soal latihan dan soal evaluasi dirancang untuk melatihkan tahap-tahap pemecahan masalah ini.

\subsection{Saran}

Berdasarkan hasil pengembangan yang telah dilakukan sebelumnya didapatkan saran (1) Sebaiknya $e$-modul berbasis multiple representation memuat materi yang memiliki banyak grafik sehingga $e$ modul yang dihasilkan dapat memuat banyak representasi (multiple representation). (2) Sebaiknya 
$e$-modul berbasis multiple representation memuat matri yang mmiliki banyak masalah sehingga $e$ modul yang dihasilkan bisa memuat semua indikator pemecahan masalah

\section{UCAPAN TERIMAKASIH}

Penulis mengucapkan terimakasih kepada validator ahli (Desy Hanisa Putri M.Si., Dr. Nirwana, M.Pd., dan Yunita Adriani, M.Pd.) yang telah membantu dalam penelitian pengembangan produk $e$ modul fisika.

\section{DAFTAR PUSTAKA}

1. Sujanem R, Suwindra INP, Tika IK. Pengembangan Modul Fisika Kontekstual Interaktif Berbasis Web Untuk Siswa Kelas. J Pendidik dan Pengajaran. 2009;4(2):97-104.

2. Aji SD, Hudha MN. Pengembangan Modul Pembelajaran Fisika Berbasis Problem Based Learning untuk Meningkatkan Kemampuan Pemecahan Masalah Fisika. Sci Educ J. 2017;1(1):36-51.

3. Sutarno, Setiawan A, Suhandi A, Kaniawati I, Putri DH. Keterampilan Pemecahan Masalah Mahasiswa Dalam Pembelajaran Bandul Fisis Menggunakan Model Problem Solving Virtual Laboratory. J Pendidik Fis dan Teknol. 2017;3(2):164-72.

4. Cahyani H, Setyawati RW. Pentingnya Peningkatan Kemampuan Pemecahan Masalah melalui PBL untuk Mempersiapkan Generasi Unggul Menghadapi MEA. In: PRISMA. Semarang: Jurusan Matematika FMIPA UNNES; 2017. p. 151-60.

5. Nurussaniah. Pengembangan modul mata kuliah pemodelan matematika berbasis pemecahan masalah pada materi sistem massa pegas. J Pendidik Inform dan Sains. 2016;5(1):105-19.

6. Departemen Pendidikan Nasional. Penulisan Modul. Jakarta: Direktorat Jenderal Peningkatan Mutu Pendidik Dan Tenaga Kependidikan Departemen Pendidikan Nasional; 2008.

7. Suarsana IM. PENGEMBANGAN E-MODUL BERORIENTASI PEMECAHAN MASALAH UNTUK MENINGKATKAN KETERAMPILAN BERPIKIR KRITIS MAHASISWA. J Pendidik Indones. 2013;2(2):264-75.

8. Kususa SA, Sudarti, Aristya PD. PENGEMBANGAN MODUL FISIKA BERBASIS KONTEKSTUAL PADA MATERI ALAT-ALAT OPTIK DALAM PEMBELAJARAN DI KELAS X SMAN 3 LUMAJANG. J Pembelajaran Fis. 2017;6(2):154-61.

9. Syafitri Y, Festiyed F, Dwiridal L, Afrizon R. PEMBUATAN E-MODUL BERORIENTASI HIGHER ORDER THINKING SKILLS ( HOTS ) UNTUK PEMBELAJARAN FISIKA PADA MATERI KALOR DAN TEORI KINETIK GAS DI KELAS XI SMA/MA. Pillar Phys Educ. 2019;12(4):777-84.

10. Pratiwi RI, Nyeneng ID, Wahyudi I. Pengembangan Modul Pembelajaran Kontekstual Berbasis Multiple Representations Pada Materi Fluida Statis. J Pembelajaran Fis. 2017;5(3):69-79.

11. Ningrum DW. Hubungan antara Optimisme dan Coping Stres pada Mahasiswa UEU yang sedang Menyusun Skripsi. J Psikol. 2010;9(1):41-7.

12. Hayati S, Budi AS, Handoko E. PENGEMBANGAN MEDIA PEMBELAJARAN FLIPBOOK FISIKA UNTUK MENINGKATKAN HASIL BELAJAR PESERTA DIDIK. In: Seminar Nasional Fisika II. Universitas Negeri Jakarta; 2015. p. 49-54.

13. Purwanto A, Sakti I, Sindita D. The development of students worksheets is oriented to the higher other thinking skill with problem solving models on electromagnetic induction materials. J Phys Conf Ser. 2021;1731:1-6.

14. Setyandaru TA, Wahyuni S, Putra PD aristya. Pengembangan modul pembelajaran berbasis multirepresentasi pada pembelajaran fisika di sma/ma. J Pembelajaran Fis. 2017;6(3):21824.

15. Puspitasari AD. PENERAPAN MEDIA PEMBELAJARAN FISIKA MENGGUNAKAN MODUL CETAK DAN MODUL ELEKTRONIK PADA SISWA SMA. J Pendidik Fis. 2019; 7(1):17-25. 